\title{
PERSIAPAN DAN KESIAPAN BERBICARA DI DEPAN PUBLIK
}

\author{
Oleh: Sri Pujiastuti
}

\begin{abstract}
Abstrak
Semua orang yang normal tentu dapat berbicara. Namun tidak semua orang dapat berbicara di depan umum (publik). Hal ini dikarenakan berbicara di depan publik memerlukan kesiapan dan persiapan yang baik. Konsep diri, tingkat kecemasan, gerak tubuh, dan penguasaan materi sangat berpengaruh terhdap kelancaran berkomunikasilisan.

Penguasaan materi perlu dilakukan dengan membuat persiapan sebelumnya, seperti mencari sumber informasi/pustaka, membuat draf atau teks pidato, bila perlu bagi pembicara pemula dapat berlatih menyajikannya. Konsep diri yang positif dan tingkat kecemasan yang rendah akan membantu kelancaran berkomunikasi, namun sebaliknya konsep diri yang rendah dan tingkat kecemasan yang tinggi akan mengganggu kelancaran berkomunikasi lisan. Hal itu karena konsep diri dan kecemasan berkomunikasi dapat berpengaruh dalam perilaku atau gerak tubuh saat berbicara. Perilaku atau gerak tubuh yang bermakna akan menunjang keberhasilan berkomunikasi, sebaliknya perilaku yang tidakberfungsi/bermaknaakan menghambat komunikasi lisan.
\end{abstract}

\section{A.Pendahuluan}

Tidak semua orang dapat atau berani berbicara di depan umum (publik). Bagi tokoh masyarakat, pemimpin, pejabat, sarjana, maupun mahasiswa sebagai calon sarjana, penguasaan keterampilan berbicara di depan publik sangat penting. Hal ini karena keterampilan tersebut diperlukan dalam menunjang kariernya melalui kemampuan menyampaikan gagasan, pendapat, usul kepada orang lain.

Dari pengalaman penulis mengajar keterampilan berbicara, ternyata jika mahasiswa mendapat tugas untuk berbicara di depan umum dalam praktik mata kuliah Berbicara, seperti misalnya dalam praktik berpidato, mereka tampak gugup, tersendat-sendat dalam mengeluarkan idenya, dan sering melakukan gerakan yang tidak mendukung. Boleh jadi hal itu dilakukan 
dengan tanpa disadari.

Keberhasilan suatu komunikasi lisan tidak hanya ditentukan oleh penguasaan faktor bahasa dan materi yang akan disampaikan saja, melainkan juga dipengaruhi oleh faktor penampilan fisik dan perilaku saat melakukan komunikasi. Konsep diri dan tingkat kecemasan seseorang merupakan faktor psikologis yang termasuk faktor nonkebahasaan yang sangat berpengaruh dalam mencapai keberhasilan atau kelancaran berkomunikasi, terutama dalam situasi resmi seperti pidato, seminar, dan sebagainya (Trefina, 1990, dan Pujiastuti, 1993).

Untuk meremidi kesalahan atau kekurangan dalam praktik berbicara di depan umum, pembicara dianjurkan mempersiapkan dan menguasai materi. Selain itu, yang bersangkutan diharapkan juga memiliki sifat-sifat orang yang berkonsep diri positif, dan berlatih agar berada dalam tingkat kecemasan yang rendah saat berkomunikasi. Untuk itu, berikut ini akan diuraikan hal-hal yang berkaitan dengan penyiapan materi, komunikasi yang efektif, konsep diri, kecemasan berkomunikasi, dan perilaku nonverbal atau gerak tubuh dalam berkomunikasi, yang merupakan kesiapan dan persiapan berbicara di depan publik. Pengetahuan tentang hal-hal yang akan diuraikan ini berguna bagai siswa, mahasiswa, guru, dosen pengampu berbicara, serta peminat lain yang akan mendalami cara bagaimana berbicara di depan publik yang berhasil.

\section{B. Efektivitas Berbicara di Depan Publik}

Keberhasilan berbicara di depan publik ditentukan oleh keefektifannya. Arsyad \& Mukti (1988: 55-56) mengemukakan bahwa faktor penunjang keefektifan berbicara (berpidato) adalah pembicara yang bermoral, sehat jasmani \& rokhani, mengeluarkan suara yang memadai, memperhatikan tingkat pengetahuan pendengar, kebiasaan, adat-istiadat, dan agama.

Gerungan (1988: 55) mengemukakan bahwa agar komunikasi dapat berhasil dengan efektif diperlukan penyesuaian diri antara pembicara dengan lingkungan di mana ia berbicara. Penyesuaian itu dapat dilakukan dengan dua cara, yaitu: (1) mengubah diri sendiri sesuai dengan lingkungannya; dan (2) m engubah lingkungan sesuai dengan keadaan atau keinginan si pembicara itu sendiri. 
Pendapat-pendapat di atas memang dapat dipahami atau dimengerti karena jika pendengar mengetahui moral si pembicara tidak baik akan berpengaruh terhadap tanggapan atau sikap pendengar terhadap pidatonya. Juga pembicara yang sehat jasmani dan rokhaninya akan berpenampilan gagah, segar, bersemangat, dan simpatik. Demikian juga volume suara yang memadai serta penguasaan terhadap tingkat pengetahuan massa, keadaan sosial, agama, dan adat-istiadat pendengar akan dapat menghindarkan diri dari cemooh, tindakan kasar atau tidak disenangi oleh pendengar.

Selain penguasaan materi, urutan penyajian juga sangat penting dalam mencapai keberhasilan komunikasi lisan di depan umum. Materi hendaknya sesuai dengan pendengar. Oleh karena itu, pembicara sebaiknya mengetahui siapa pendengarnya, dari lingkungan mana pendengarnya, dan sebagainya.

\section{Konsep Diri dalam Berbicara di Depan Publik}

Konsep diri merupakan faktor psikologis yang sangat berpengaruh terhadap komunikasi. Konsep diri berkaitan erat dengan kecemasan berkomunikasi. Menurut Alder dan Rodman (via Trefina, 1990: 14), konsep diri adalah persepsi seseorang yang mendalam dan relatif tetap terhadap dirinya, yang meliputi sesuatu yang khas pada dirinya, sesuatu yang sama, dan yang berbeda dengan orang lain. Menurut Rakhmat (1989: 112), konsep diri adalah persepsi atau gambaran deskriptif dan penilaian terhadap dirinya, yang meliputi apa yang dipikirkan dan yang dirasakan. Dari uraian di atas, dapat dilihat adanya dua komponen dalam diri, yaitu kognitif dan afektif.

Dalam psikologi sosial komponen kognitif disebut citra diri (self image) dan komponen afektif disebut harga diri (self esteem). Kedua komponen itu sangat berpengaruh terhadap lancarnya komunikasi lisan karena setiap perilaku seseorang sedapat mungkin akan disesuaikan dengan konsep dirinya. Hal ini karena konsep diri yang positif akan melahirkan pola perilaku dan ucapan positif pula. Sebaliknya, konsep diri yang negatif akan melahirkan pola perilaku dan ucapan yang negatif, yang akhirnya akan meng urangi efektivitas komunikasinya.

Selanjutnya Hamachek (via Rakhmat, 1989: 112-120) mengemukakan bahwa karakteristik orang yang memiliki konsep diri positif, yaitu: (1) 4)

Persiapan dan Kesiapan Berbicara di Depan Publik (Sri Pujiastuti) 
meyakini dan mempertahankan nilai dan prinsip yang dipegangnya; (2) bertindak bijaksana bila orang lain tidak setuju dengan pendapat atau tindakannya; (3) selalu memandang positif hari esok; (4) yakin pada kemampuannya dalam mengatasi masalah; (5) sanggup dianggap orang penting; (6) merasa sama dengan orang lain (tidak merasa lebih tinggi atau lebih rendah); (7) dapat menerima pujian tanpa rasa malu; (8) cenderung menolak didominasi oleh orang lain; (9) bersedia mengakui perasaan yang ada di hatinya; (10) mampu menerima keadaan dirinya; dan (11) peka terhadap kebutuhan orang lain.

Karakteristik yang dimiliki oleh orang yang berkonsep diri negatif adalah: (1) peka, tidak tahan, dan mudah marah terhadap kritik; (2) senang dipuji; (3) selalu meremehkan, mencela, tidak mau menghargai kelebihan orang lain; dan (4) merasa tidak disenangi orang lain.

Kenyataan yang ada di masyarakat memang tidak ada orang yang benar-benar berkonsep diri negatif atau positif sepenuhnya, namun untuk berkomunikasi secara efektif dalam komunikasi lisan sedapat mungkin tanda atau karakteristik orang yang berkonsep diri positif itu banyak dimiliki oleh pembicara atau komunikator. Dengan demikian, untuk menjadi pembicara yang baik kita dapat membuka diri, percaya diri, ramah, dan menghargai orang/pendengar lain agar disenangi oleh pendengar atau lawan bicaranya. Hal ini akan membuat komunikasi efektif. Sikap orang tua, guru atau dosen demokratis, ramah, dan bersahabat dapat memupuk konsep diri yang positif.

Pendengar atau lawan bicara dapat menduga karakteristik pembicara dari petunjuk eksternal yang dapat diamati lewat panca indera. petunjukprtunjuk itu adalah: deskripsi verbal dari pihak ketiga, petunjuk proksemik, kinesik, dan wajah. Proksemik, kinesik, dan raut wajah itu termasuk perilaku nonverbal yang dapat dilatih agar dapat menggambarkan kepercayaan diri untuk mendukung komunikasi yang efektif.

Konsep diri merupakan produk interaksi sosial karena gambaran konsep diri merupakan refleksi dari penilaian orang lain yang ada di sekelilingnya tentang dirinya. Mengenai lingkungan ini, keluarga merupakan lingkungan yang pertama bagi seseorang untuk menerima berbagai penilaian, setelah itu lingkungan pergaulan, sekolah, dan lingkungan pekerjaan.

DIKSI, Vol.7 No.18 Oktober 2000 
Keluarga yang demokratis, tidak otoriter dengan sosial ekonomi cukup, serta tentram sangat mendukung munculnya konsep diri positif bagi anggota keluarganya. Pujian yang wajar serta penghargaan terhadap apa yang dilakukan anggotanya akan merupakan motivasi munculnya konsep diri positif.

Selain penilain dari orang lain, konsep diri juga merupakan hasil perbandingan dirinya dengan orang lain. Misalnya saja seseorang akan merasa kecil/rendah dibandingkan dengan atasan/bosnya, namun merasa besar/tinggi dibandingkan dengan pembantunya. Untuk itu, lingkungan pergaulan yang saling menghargai akan membantu terbentuknya konsep diri positif. Pemberian kesempatan berbicara pada siswa di kelas dapat membantu ia percaya diri dan menumbuhkan konsep diri positif.

\section{Kecemasan dalam Berbicara di Depan Publik}

Meskipun komunikasi bukan merupakan kegiatan yang asing bagi manusia sebagai makhluk sosial, namun ia sering merasa cemas dalam menghadapi situasi komunikasi dengan orang lain, terutama dalam menghadapi di depan umum. Trefina (1990:31-32) mengemukakan beberapa pendapat para ahli tentang definisi kecemasan yang bila dirangkum adalah sebagai berikut. Kecemasan dalam komunikasi adalah kondisi seseorang yang memiliki gangguan mental berupa kekhawatiran dan kegelisahan dalam menghadapi situasi komunikasi karena adanya ancaman terhadap rasa aman dan nyaman pada dirinya.

Tingkat kecemasan yang tinggi sangat mengganggu efektivitas komunikasi, sebaliknya tingkat kecemasan yang rendah atau bahkan tidak adanya perasaan cemas akan sangat mendukung keberhasilan komunikasi. Trefina (1990:34-36) mengemukakan bahwa ada berbagai bentuk reaksi yang dapat dilihat akibat adanya kecemasan komunikasi yang dialami pembicara, yaitu: (1) kesukaran dalam menyusun pikiran/kata-kata; (2) adanya reaksi fisiologis: denyut jantung lebih cepat, wajah memerah, keringat dingin keluar pada telapak tangan, leher, dan dahi; (3) adanya reaksi psikologis: tampak gugup, bingung, dan tegang; dan (4) adanya reaksi yang berkaitan dengan kebiasaan-kebiasaanya: memegang-megang hidung, menghindari kontak 
mata dengan pendengar, menggerak-gerakkan mulut atau kebiasaankebiasaan lain yang mengganggu komunikasi.

Bentuk reaksi tersebut akan muncul manakala pembicara memiliki kecemasan dalam komunikasi, yang istilah umumnya adalah demam panggung jika ia sedang berada di depan umum. Kecemasan berkomunikasi lisan dipengaruhi oleh konsep dirinya. Semakin rendah atau negatif konsep diri seseorang, maka semakin tinggi tingkat kecemasan yang dimilikinya bila ia berada di depan umum.

Untuk mengurangi atau mencegah timbulnya kecemasan dalam komunikasi oral/lisan dapat dilakukan dengan banyak membaca dan bergaul, serta berlatih berbicara di depan umum, dimulai berbicara di depan kelas, di lingkungannya, dan seterusnya. Untuk itu, urutan latihan dalam pengajaran berbicara sebaiknya dimulai dari berbicara berkelompok (diskusi, debat), baru perorangan (perkenalan diri, pidato). Hal ini agar mengurangi rasa takut siswa, dan secara bertahap dapat berani di depan umum. Selain itu, orang tua, guru, dosen yang demokratis, ramah, dan bersahabat akan mengurangi kecemasan berkomunikasi anak, siswa, atau mahasiswa.

\section{E. Gerak Tubuh dalam Berbicara di Depan Publik}

Meskipun telah diakui bahwa bahasa itu merupakan alat komunikasi, namun pembicara masih sering juga menggunakan perilaku nonverbal atau gerak tubuh dalam komunikasinya. Hal itu karena perilaku nonverbal dapat digunakan juga untuk menyampaikan maksud atau gagasannya. Gerak tubuh atau perilaku nonverbal yang mendukung keberhasilan komunikasi adalah bila perilaku tersebut memiliki fungsi atau arti. Jika tidak memiliki arti, maka perilaku nonverbal tersebut hanya akan mengganggu komunikasi saja, m isalnya membuat pendengar merasa risih, muak, dan sebagainya. Pesan yang disampaikan melalui perilaku nonverbal disebut pesan nonverbal.

Berbagai fungsi perilaku nonverbal yang digunakan dalam komunikasi itu menurut Mark L. Knapp (1972: 9-12) dikelompokkan menjadi lima, yaitu: (1) repetisi: mengulang kembali gagasan yang sudah dikemukakan secara verbal; (2) substitusi: menggantikan lambang verbal; 93) kontradiksi: memberikan makna yang berlawanan terhadap pesan verbal yang

DIKSI, Vol.7 No.18 Oktober 2000 
disampaikan; (4) komplemen: melengkapi dan memperkaya makna pesan noverbal; dan (5) aksentuasi: menegaskan atau menggarisbawahi pesan verbal.

Perilaku verbal yang memiliki makna di atas akan membantu keberhasilan dalam berkomunikasi oral. Sebaliknya perilaku nonverbal yang tidak bermakna dan yang biasanya dilakukan dengan tidak sengaja karena adanya kecemasan dalam komunikasi lisan akibat konsep diri negatif yang dimilikinya akan menghambat kelancaran dan efektivitas komunikasi.

Kelebihan perilaku nonverbal menurut Dale G. Leathers (1976: 4-7) adalah: (1) perilaku nonverbal sangat menentukan makna dalam komunikasi interpersonal; (2) perasaan dan emosi lebih cermat disampaikan lewat pesan nonverbal daripada verbal; (3) pesan nonverbal dapat menyampaikan maksud yang relatif bebas dari kebohongan dan distorsi; (4) pesan nonverbal memiliki metakomunikasi yang sangat diperlukan untuk mencapai komunikasi yang berkualitas tinggi karena menambah kadar informasi dalam penyampaian pesan; (5) penggunaan pesan nonverbal merupakan cara berkomunikasi yang lebih efisien daripada pesan verbal; dan (6) pesan nonverbal merupakan cara mem berikan sugesti yang tepat. Berbagai kelebihan itulah yang menyebabkan perilaku nonverbal digunakan oleh pembicara untuk mencapai komunikasi yang efektif. Gerak tubuh yang menunjang komunikasi ini perlu dilatih pada pembicara pemula, siswa dan mahasiswa.

\section{F. Materi dan Cara Penyajiannya}

Uraian berikut berkaitan dengan komunikasi lisan dalam situasi resmi. Dalam komunikasi lisan yang resmi atau setengah resmi, penguasaan materi tidak kalah penting dibandingkan dengan faktor konsep diri, kecemasan, dan perilaku nonverbal. Pembicara yang tidak menguasai materi yang akan dibicarakannya akan membuatnya kurang percaya diri, yang akhirnya dapat menimbulkan adanya kecemasan dalam komunikasi yang dapat diketahui oleh pendengarnya. Hal itu dapat mengurangi penghargaan pendengar terhadap dirinya, pendengar akan kecewa bila mengetahui bahwa pembicara tidak menguasai materi yang akan dibawakannya. Oleh karena itu, pembicara perlu mencari dan mengumpulkan informasi dari berbagai sumber, seperti: 
buku, media elektronik maupun nonelektronik, serta pengalaman empiris yang dialami oleh orang lain maupun dialaminya sendiri.

Materi yang dibawakan pembicara hendaknya sesuai dengan pendengar, dalam arti sesuai dengan usia, tingkat pengetahuan, adat, tingkat sosial, bahkan juga lingkungannya. Selain itu, materi yang baik adalah materi yang aktual, bermanfaat, dan sesuai dengan kebutuhan pendengar.

Materi yang dibuat perlu mempertimbangkan urutan dan bahasanya. Untuk membuat materi yang baik hendaknya dipersiapkan dengan matang, kalau perlu dengan membuat kerangka karangan. Bagi pembicara pemula perlu banyak latihan.

Sedangkan cara penyampaian gagasan atau materi di depan umum dapat dilakukan secara mendadak (impromptu), tanpa persiapan (extemporaneous), membaca naskah, dan menghafal/hafalan.

Cara mendadak dilakukan bila tiba-tiba seseorang diminta untuk berbicara tanpa diberitahu sebelumnya. Materi yang dikemukakan hendaknya umum dan singkat. Extemporaneous dilakukan oleh pembicara yang cukup berpengalaman, yakni hanya dengan membawa garis besar apa yang akan dikemukakannya sehingga ia lebih leluasa dalam menyampaikannya. Berbicara atau berpidato dengan membaca naskah biasanya dilakukan bila apa yang akan dikemukakannya itu penting. Artinya, kesalahan ucapan akan berakibat fatal atau akan mempunyai pengaruh yang besar. Sedangkan cara hafalan hampir tidak pernah dilakukan orang. Cara ini biasanya untuk pembicara pemula atau anak sekolah yang mendapat tugas berbicara dari gurunya.

Adapun upaya untuk meyakinkan seseorang bahwa apa yang dibicarakannya itu benar atau dapat dipercaya menurut Aristoteles dalam Dipodjojo (1982: 36-37) adalah dengan menggunakan ethos, logos, dan pathos. Ethos adalah upaya meyakinkan pendengar atas dasar reputasi dan pengalaman pembicara. Cara menyakinkan pendengar lewatlogos atau logika adalah bila uraiannya sesuai dengan nalar. Dan cara meyakinkan lewat $p h a t o s$ adalah pendekatan lewat perasaan. Pembicara yang baik akan menyakinkan pendengar lewat menyentuh perasaannya, misalnya pembicara dalam cara amal untuk bencana alam, panti jompo, dan yatim piatu, atau kegiatan sosial la innya. Dengan mengetahui cara-cara meyakinkan pendengar terhadap apa yang dikatakannya, hal ini akan meningkatkan keberhasilan dalam komunikasi lisan.

Bagi pembicara pemula dianjurkan sering berlatih, membuat materi, m enggunakan gerak tubuh yang menunjang, serta melisankan menggunakan

DIKSI, Vol.7 No.18 Oktober 2000 
volume, tekanan, irama yang baik sebelum penyampaian pidato atau pelaksanaan berbicara di depan umum yang sebenarnya dilakukan.

\section{G. Kesimpulan}

Berdasarkan uraian di atas, akhirnya dapat disimpulkan hal-hal sebagai berikut.

1. Berbagai hambatan yang sering dialami pembicara ialah menyangkut konsep diri negatif, kecemasan berkomunikasi yang tinggi, perilaku nonverbal yang kurang mendukung komunikasi, dan penguasaan materi serta penyajiannya yang kurang baik. Untuk itu, perlu diupayakan dimilikinya konsep diri yang positif, tingkat kecemasan berkomunikasi yang rendah, pengusaan materi, dan latihan penyajian. Hal itu dapat dilakukan melalui penciptaan keluarga, guru, dosen, serta lingkungan pergaulan yang demokratis, bersahabat, dan saling menghargai.

2. Latihan perlu banyak dilakukan bagi pembicara pemula baik dalam penyusunan materi, maupun dalam penyajiannya. Untuk mengurangi tingkat kecemasan berkomunikasi siswa/mahasiswa, guru/dosen diharapkan banyak memberikan latihan berbicara, dimulai di dalam kelompok (diskusi, debat), dan baru secara individual (pidato).

\section{DAFTAR PUSTAKA}

Arsyad, M.G \& Mukti U.S. 1988. Pembinaan Kemampuan Berbicara Bahasa Indonesia. Jakarta: Erlangga.

Dipodjojo, Asdi S. 1982. Komunikasi Lisan. Yogyakarta: Pd. Lukman.

Knapp, M.L. 1972. Nonverbal Communication in Human Interaction. New York: Holt, Rinehart and Winston.

Leathers, D.G. 1976. Nonverbal Communication System. Sydney: Allyn and Bacon Inc.

Pujiastuti, Sri. 1992. Perilaku Berpidato sebagai Cerminan Konsep Diri Mahasiswa Semestr 3 Jurusan Bahasa dan Sastra Indonesia FPBS IKIP Yogyakarta. IKIP Yogyakarta: Laporan Penelitian.

Rakhmat, Jalaludin. 1989. Psikologi Komunikasi. Bandung: Remaja Karya Offset.

Persiapan dan Kesiapan Berbicara di Depan Publik (Sri Pujiastuti) 
Trefina, Ina. 1990. Hubungan antara Konsep Diri dengan Kecemasan Komunikasi Oral pada Mahasiswa FIP, FPBS, FPIPS di IKIP Yogyakarta. Fakultas Psikologi UGM. Skripsi (tidak diterbitkan). 